\begin{tabular}{|c|c|}
\hline 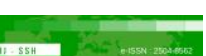 & Malaysian Journal of Social Sciences and Humanities (MJSSH) \\
\hline Malaysian Journal of & Volume 5, Issue 12, December 2020 \\
\hline (MJ-SSH) & e-ISSN : 2504-8562 \\
\hline & $\begin{array}{l}\text { Journal home page: } \\
\text { www.msocialsciences.com }\end{array}$ \\
\hline
\end{tabular}

\title{
Kemahiran Penyelesaian Masalah Berayat Matematik Melalui Model Bar: Sorotan Literatur Bersistematik
}

\author{
Wong Wan Ting1, Mohd Effendi @ Ewan Mohd Matore ${ }^{1}$ \\ ${ }^{1}$ Fakulti Pendidikan, Universiti Kebangsaan Malaysia (UKM) \\ Correspondence: Mohd Effendi @ Ewan Mohd Matore (effendi@ukm.edu.my)
}

\begin{abstract}
Abstrak
Model Bar merupakan lukisan model atau kaedah model dengan membina gambar rajah daripada masalah berayat matematik. Justeru, kajian ini bertujuan untuk mengkaji trend pelaksanaan strategi Model Bar dalam menyelesaikan masalah berayat dalam matematik berdasarkan empat kriteria. Empat kriteria merupakan kriteria pangkalan data, tahun penerbitan artikel, lokasi kajian dijalankan dan skop kajian. Terdapat empat pangkalan data iaitu Web of Science (WOS), Scopus, Semantic Scholar dan Lainlain pangkalan data jurnal digunakan dalam saringan artikel-artikel kajian lepas. Prosedur sorotan literatur bersistematik (SLR) digunakan merangkumi reka bentuk, strategi dan kata kunci pencarian artikel, kriteria pemilihan artikel, proses pemilihan artikel serta proses pengumpulan dan penganalisisan artikel. Terdapat 20 buah artikel dianalisis dan telah dipilih dalam kajian ini dengan berlandaskan empat kriteria tersebut. Dapatan kajian menunjukkan bahawa keberkesanan penggunaan strategi Model Bar banyak dikaji di negara-negara luar seperti Indonesia, Australia, United State, Amerika, Brunei dan Filipina. Namun demikian, kajian ini kurang penerbitan dalam masa lima tahun yang terkini. Maka, tempoh tahun penghasilan artikel yang berkaitan dipanjangkan sehingga 10 tahun yang terkini. Pangkalan data Semantic Scholar menyumbang paling banyak artikel dalam kajian ini. Tiga skop kajian telah dianalisis iaitu keberkesanan penggunaan Model Bar terhadap penyelesaian masalah matematik, persepsi guru dan murid terhadap penggunaan Model bar dalam penyelesaian masalah matematik dan perbezaan antara penggunaan strategi Model Bar dengan pendekatan konvensional terhadap pencapaian murid. Cadangan kajian lanjutan yang boleh dibuat ialah dengan mendedahkan Model Bar kepada murid konteks lain melalui teknik visualisasi secara lebih holistik.
\end{abstract}

Kata kunci: model bar, Kemahiran Berfikir Aras Tinggi (KBAT), penyelesaian masalah berayat matematik, kemahiran matematik, sekolah rendah

\section{Mathematical Problem Solving Through Bar Model: Systematic Literature Review}

\begin{abstract}
Model Bar is a model drawing or model method by constructing diagrams from a mathematical problem. The study aims to examine the trend of implementation of the Bar Model strategy in solving problem Mathematics based on four criteria which is database, year of publication of article, location of study conducted and scope of study. There are four databases namely Web of Science (WOS), Scopus, Semantic Scholar and other journal databases have been used in this study. Systematic Literature Review
\end{abstract}


(SLR) procedures used include the design, strategies and keywords of articles search, article selection criteria, article selection process. There are 20 articles analyzed based on these four criteria. The findings show that the effectiveness of the Bar Model is widely studied in foreign countries such as Indonesia, Australia, United States, America, Brunei and the Philippines. Nevertheless, this study lacked publication in the last five years. Therefore, year of publications is extended to the latest 10 years. Most of the articles collected and screened are from the Semantic Scholar database as it is one of the databases that produces academic publications. Three scopes of the study were analyzed were the effectiveness of the use of Bar Model on Mathematical problem solving, teachers and students' perceptions on the use of Bar Model in Mathematical problem solving and the difference between the use of bar Model strategy and conversional approach to student achievement. The suggestion of future research is to expose the Bar Model to students of other contexts through more holistic visualization techniques.

Keywords: Bar Model, High Level Thinking Skills (HOTS), mathematical sentence problem solving, mathematic skills, primary school

\section{Pengenalan}

Pendidikan merupakan agen perubahan dan pembangunan kepada sesebuah negara. Dalam kepesatan pembangunan Negara, pemimpin dan rakyat yang maju dan berfikiran aras tinggi adalah landasan bagi melahirkan modal insan yang harmoni. Pemikiran kreatif dan kritis menjadikan masyarakat berfikiran lebih saintifik, tidak ketinggalan serta mampu bersaing di persada dunia. Pendidikan bertaraf dunia akan menentukan kejayaan perubahan seseorang individu.

Transformasi pendidikan tidak dapat dielakkan kerana setiap ilmu pengetahuan, penerokaan dan penemuan akan berubah ke arah yang semakin baik dan maju. Pendidikan merupakan suatu proses dan aktiviti yang bertujuan memberikan perubahan kepada masyarakat mengikut norma dan nilai masyarakat. Oleh itu, terdapat pelbagai faktor yang menyumbang ke arah perubahan dalam pendidikan sama ada daripada faktor luaran mahupun faktor dalaman yang mendesak serta memberi tekanan untuk melakukan perubahan dinamik dalam bidang pendidikan. Selain itu, guru adalah bertanggungjawab menyampaikan pendidikan dan perlu mempertingkatkan profesionalisme kendiri dahulu sebelum berhadapan dengan murid.

Berdasarkan keputusan pencapaian Trends in International Mathematics dan Science Study (TIMSS) dan Programme for International Student Assessment (PISA) baru-baru ini, keputusan yang rendah bagi pelajar Malaysia amat membimbangkan semua pihak. Asasnya, TIMSS dilihat tertumpu kepada soalan yang berbentuk penyelesaian masalah yang mempunyai elemen KBAT. Malangnya pencapaian Malaysia dalam TIMSS bagi matematik menurun secara signifikan di mana Malaysia terletak dalam kelompok satu pertiga terbawah dalam kalangan negara-negara peserta. Manakala bagi keputusan pencapaian PISA pada Tahun 2018 pula mencatatkan 431 mata iaitu di bawah 450 mata. Nilai 450 mata merupakan penanda aras dan nilai purata bagi keputusan PISA. Kedudukan pencapaian Malaysia adalah jauh lebih rendah daripada kedudukan negara jiran seperti Singapura dan Vietnam. Pencapaian Malaysia dalam TIMSS dan PISA telah mempengaruhi kedudukan Malaysia dalam "ranking" antarabangsa yang selalu digunakan sebagai satu indikator bagi pengukuran kualiti sistem pendidikan. Keputusan TIMSS dan PISA ini menunjukkan murid kita mempunyai penguasaan konsep asas matematik yang terhad.

Kurikulum Bersepadu Sekolah Rendah (KBSR) telah lama diperkenalkan pada Tahun 1983. Sebagai langkah transformasi pendidikan, Kurikulum Standard Sekolah Rendah (KSSR) diperkenalkan sejak Tahun 2011. KSSR diperkenalkan atas dasar membangunkan modal insan yang mempunyai pengetahuan dan kemahiran serta menghayati nilai-nilai murni. KSSR matematik yang dilaksanakan bukan sahaja menimba ilmu pengetahuan terhadap empat operasi asas matematik malahan lebih menumpukan kepada Kemahiran Berfikir Aras Tinggi (KBAT) terutamanya bagi penyelesaian masalah rutin dan masalah bukan rutin. KSSR memberi penekanan yang besar kepada pembangunan pemikiran matematik melalui penyelesaian masalah. Selain itu, KSSR telah diperkenalkan untuk mengatasi 
kekurangan dan kelemahan dalam sistem KBSR. KSSR direkabentuk dengan bertujuan untuk mengembangkan kemahiran berkomunikasi, kemahiran berfikir, pembangunan kendiri dan penyesuaian diri dengan persekitaran dalam kehidupan seharian.

Pembelajaran abad ke-21 menekankan elemen KBAT dalam kurikulum matematik. Tahap kognitif yang paling dominan yang diperhatikan dalam kalangan murid ialah aplikasi malah kurang tahap kognitif seperti kreatif, kritis dan inovatif (Malaysia Education Blueprint, 2013). Terdapat 20\% item KBAT telah diterapkan dalam matematik Ujian Pencapaian Sekolah Rendah (UPSR) pada Tahun 2016 dan peratusan item KBAT akan bertambah dari semasa ke semasa. Akan tetapi, murid Tahun 6 kurang bersedia dan kurang mampu menjawab soal an KBAT dengan jayanya (Marzita et al., 2017). Kemahiran berfikir boleh didefinisikan sebagai proses menggunakan minda untuk mencari makna dan pemahaman terhadap sesuatu, menerokai pelbagai kemungkinan idea atau ciptaan, membuat keputusan dan menyelesaikan masalah dan seterusnya membuat refleksi dan metakognitif terhadap proses yang dialami (Lembaga Peperiksaan, 2013). Proses ini penting untuk merangsang pemikiran murid ke arah yang lebih kritis dengan meneroka mungkin lebih daripada satu jawapan yang munasabah bagi suatu penyelesaian masalah. Oleh itu, kepelbagaian strategi penyelesaian masalah adalah sangat penting agar murid dapat menjawab masalah bukan rutin yang berelemen KBAT.

Kajian ini menunjukkan terdapat banyak kajian lepas yang telah dilaksanakan bagi menilai keberkesanan penggunaan strategi Model Bar dari aspek meningkatkan pencapaian murid dalam menguasai kemahiran menyelesaikan masalah berayat matematik. Kajian trend penyelidikan ini dapat membantu pengkajipengkaji lain untuk membuat kajian lanjutan pada masa hadapan. Terdapat cadangan yang boleh diusulkan bagi kajian lanjutan seterusnya. Pada masa akan datang, dicadangkan penggunaan strategi Model Bar boleh dijalankan kepada kumpulan sasaran yang terdiri daripada murid Tahap 1. Ini kerana perkembangan kognitif kanak-kanak adalah berkait rapat dengan peringkat umur mereka. Kanak-kanak yang berusia 7 tahun hingga 11 tahun merupakan peringkat pra-operasi. Pada peringkat ini mereka akan membuat penaakulan logik tetapi masih terikat-ikat kepada objek atau kejadian yang lebih konkrit. Dengan itu, adalah sesuai bagi warga pendidik mendedahkan strategi Model Bar dalam pengajaran dan pembelajaran matematik pada peringkat yang seawal Tahap 1 iaitu Tahun 1 hingga Tahun 3.

\section{Sorotan Literatur}

\section{Penyelesaian Masalah Matematik}

Penyelesaian masalah merupakan kemahiran yang sangat penting dalam subjek matematik di semua peringkat persekolahan. Penyelesaian masalah ialah proses pembelajaran yang menggalakkan pelajar menggunakan KBAT dalam PdPc matematik. Terdapat empat komponen utama proses kognitif bagi kemahiran penyelesaian masalah iaitu perwakilan, perancangan / pemantauan, pelaksanaan dan refleksi kendiri. Model Polya mencadangkan empat langkah bagi penyelesaian masalah matematik iaitu memahami masalah, merangka / merancang, menjalankan perancangan dan semak semula jawapan dalam langkah merancang penyelesaian. Murid didedahkan dengan pelbagai strategi penyelesaian masalah yang dianggap bersesuaian dengan situasi masalah tersebut.

Pendidikan matematik merangkumi dua jenis pengetahuan yang perlu dikuasai oleh setiap murid iaitu ilmu pengetahuan tentang suatu kemahiran dan pengetahuan tentang penyelesaian masalah tersebut. Kedua-dua aspek ini adalah penting supaya pembelajaran yang dilaksanakan adalah bersifat berkesan. Kefahaman konsep memerlukan pengetahuan tentang konsep tertentu, bagaimana ia berkaitan dengan idea yang telah diperoleh, hubung kait antara konteks dan limitasinya (Mclntosh, 2002). Bagi mengatasi masalah matematik berayat, satu cara yang sesuai haruslah dikenal pasti untuk membantu murid (Samsudin \& Fatimah, 2003). Proses penyelesaian masalah merujuk kepada kecenderungan murid melaksanakan langkah-langkah penyelesaian untuk menjawab soalan-soalan atau masalah berayat yang dikemukakan. 
Selain daripada Model Polya, Mayer telah membuat sumbangan besar kepada teori penyelesaian masalah berayat pada awal 1980-an. Beliau menekankan kepentingan Fasa Perwakilan iaitu lukisan model sebagai langkah penyelesaian masalah. Dengan itu, Mayer kemudian mencadangkan proses dua peringkat untuk proses penyelesaian masalah yang menggabungkan apabila dan di mana jenis pengetahuan itu digunakan dalam proses penyelesaian masalah berayat (Mahoney, 2012). Sehubungan itu, pengajaran matematik terutamanya konsep penyelesaian masalah hendaklah menggunakan kaedah yang sesuai dan berkesan supaya tidak menimbulkan rasa takut atau tidak yakin di kalangan murid. Dengan ini, guru seharusnya bijak dan kreatif menggunakan kepelbagaian pendekatan penyelesaian masalah agar dapat mewujudkan suasana pembelajaran yang efektif dan produktif (Mohd Salahuddin, 2006).

\section{Model Bar}

Model Bar diperkenalkan di Singapura pada awal 1980-an. Ia telah memberikan sumbangan besar kepada pelajar dalam pembelajaran matematik mereka. Model ini memainkan peranan yang penting terutamanya dalam kurikulum matematik sekolah rendah di Singapura. Dalam strategi Model Bar, murid akan melukis gambar rajah yang berbentuk bar (palang) segi empat tepat. Mereka menggunakan bar tersebut untuk mewakili dan menggambarkan hubungan antara masalah matematik dengan penyelesaiannya berdasarkan maklumat-maklumat yang dikemukakan. Saiz bar adalah berbeza dari aspek panjang dan lebarnya. Panjang dan lebar yang berlainan digunakan untuk mewakili bilangan atau nombor yang berbeza.

Bar juga akan dibahagikan kepada beberapa bahagian yang sama besar untuk menjelaskan perbandingan terhadap konsep "lebih daripada" atau "kurang daripada". Melukis bar bukan sahaja membolehkan murid untuk menggambarkan maklumat abstrak yang diberikan malah dapat membantu murid mewakilkan kuantiti yang diketahui dan tidak diketahui untuk menyelesaikan masalah matematik. Chan dan Foong (2013) menjelaskan bahawa model ini beralih fokus daripada hasil kepada proses kerja dan daripada pengiraan kepada hubungan antara kuantiti yang diketahui dan tidak diketahui. Lebih-lebih lagi, ia membantu pelajar mengenal pasti operasi dan langkah yang betul untuk menyelesaikan masalah (Englard, 2010).

Willyarto dan Chairiyani (2015) menyatakan Model Bar adalah kemahiran metakognitif dalam kalangan pelajar supaya mereka berfikir terlebih dahulu, memahami masalah, menentukan strategi penyelesaian masalah dan menyelesaikan masalah. Model bar merupakan strategi alternatif yang boleh membantu mengatasi masalah memahami masalah berayat dan menghasilkan penyelesaian matematik (Maimunah et al., 2019).

\section{Tujuan dan Persoalan Kajian}

Kajian ini bertujuan untuk meninjau, meneroka dan mensintesiskan dapatan kajian lepas mengenai trend keberkesanan penggunaan Model Bar di semua peringkat pendidikan sama ada tadika, sekolah rendah, sekolah menengah mahupun institusi pendidikan tinggi menggunakan kajian literatur bersistematik atau Systematic Literature Review (SLR). Justeru, SLR ini dijalankan untuk menjawab persoalan berikut: Sejauhmanakah trend keberkesanan pelaksanaan strategi Model Bar dalam menyelesaikan masalah berayat matematik berdasarkan pangkalan data, tahun penerbitan artikel, lokasi kajian dan skop kajian?

Kajian melalui analisis artikel mengenai kandungan ini diharapkan dapat memberi gambaran sebenar dan keyakinan kepada para guru terhadap kesesuaian dan keberkesanan penggunaan Model Bar dalam proses pengajaran dan pemudahcaraan $(\mathrm{PdPc})$ matematik.

\section{Metod Kajian}

\section{Reka Bentuk}


Kajian literatur bersistematik merupakan satu kajian tinjauan untuk mengenal pasti, memilih dan menilai secara kritis penyelidikan untuk menjawab soalan yang dirumuskan dengan jelas (Dewey \& Drahot, 2016). SLR berusaha untuk mensintesiskan semua bukti empirikal dengan memenuhi kriteria kelayakan yang ditentukan dalam kajian berkenaan. Terdapat tujuh prinsip utama SLR iaitu ketelusan, kejelasan, kesepaduan, fokus utama, keadilan, kebolehan dan ketercapaian kawasan (Pittway, 2008). SLR seharusnya mengikuti protokol atau perancangan yang jelas kerana setiap kriteria akan dinyatakan dengan jelas sebelum suatu kajian SLR dilaksanakan. Di samping itu, SLR juga merupakan komponen penting dalam membuat kerangka teori dan membina model sesuatu konsep.

\section{Strategi dan Kata Kunci Pencarian Artikel}

Sorotan literatur bersistematik ini telah menggunakan empat pangkalan data untuk mencari dan memilih artikel yang sesuai. Ini kerana selepas proses pencarian artikel dalam hanya satu atau dua pangkalan data didapati artikel mengenai Model Bar sukar dijumpai terutamanya berkaitan dengan bidang pendidikan. Pangkalan data yang terkemukakan adalah Web of Science (WOS), Scopus, Semantic Scholar dan Lainlain (Jurnal). Dalam konteks kajian ini, Lain-lain (jurnal) merujuk kepada artikel-artikel yang diperoleh daripada Jurnal Dunia Pendidikan, Journal of Physics, International Journal of Interactive Mobile Techonologies, International Journal of Emerging Technologies in Learning, International Journal of Instruction, Universal Journal of Educational Research, International Journal of Innovative Technology and Exploring Engineering (IJITEE), South African Journal of Education, International Journal of Engineering \& Technology, Journal on Education Mathematics, International Journal of Academic Research in Progressive Education and Development dan International Journal of Psychosocial Rehabilitation.

Beberapa kata kunci telah digunakan untuk memastikan artikel-artikel yang dicari adalah bersesuaian dengan tajuk dan persoalan kajian. Kata-kata kunci yang dipilih dalam pencarian artikel ialah Model Bar (Bar Model), strategi penyelesaian masalah matematik, kemahiran berfikir aras tinggi (KBAT) atau Higher Order Thinking Skills (HOTS) dan keberkesanan Model Bar. Akhirnya, 23 buah artikel telah pun dijumpai dalam pangkalan data jurnal berkenaan dengan menepati kriteria pemilihan artikel-artikel yang ditetapkan.

\section{Kriteria Pemilihan Artikel}

Terdapat beberapa kriteria pemilihan artikel ditetapkan khusus dalam proses pemilihan artikel sebelum melaksanakan analisis dan sintesis terhadap kandungan artikel tersebut. Jadual 1 menunjukkan kriteria pemilihan dan penolakan terhadap artikel yang bersesuaian. Antara kriterianya adalah artikel yang dipilih terdiri daripada artikel prosiding dan artikel jurnal penyelidikan. Selain itu, artikel dalam 10 tahun yang terkini iaitu Tahun 2011 hingga Tahun 2020 dipilih dan dimasukkan dalam proses menganalisis dapatan. Ini kerana artikel mengenai Model Bar terhad dan sukar dijumpai dalam masa lima terkini. Pengkaji telah memperluaskan pencarian sehingga melihat kajian lepas dalam lingkungan 10 tahun yang terkini.

Jadual 1: Kriteria Pemilihan Artikel

\begin{tabular}{ccc} 
Kriteria & Layak / Terima & Pengecualian / Tolak \\
Jenis Bahan & Artikel prosiding \& jurnal & Kertas konsep, kertas cadangan \& \\
penyelidikan & bab dalam buku \\
Tahun Penerbitan & Tahun 2011 - Tahun 2020 & Sebelum Tahun 2011 \\
Bahasa & Bahasa Malaysia atau Bahasa & Bahasa selain daripada Bahasa \\
& Inggeris & Melayu \& Bahasa Inggeris \\
Lokasi Kajian & Dalam negara \& luar negara & - \\
Penyelidik Kajian & Guru & Selain daripada guru \\
Responden Kajian & Guru \& pelajar & Selain daripada guru \& pelajar \\
\hline
\end{tabular}


Oleh kerana Model Bar merupakan satu kaedah yang dibangunkan di Singapura dan dipraktikkan oleh negara-negara lain dalam bidang pendidikan, maka kebanyakan kajian yang dijalankan adalah dilaporkan dalam Bahasa Inggeris. Namun, terdapat juga artikel yang dihasilkan oleh pengkaji Malaysia dan dilaporkan dalam Bahasa Malaysia. Bagi artikel-artikel yang dipilih, lokasi kajian merupakan salah satu kriteria pemilihan artikel juga. Pengkaji menetapkan kriteria di mana kajian yang dijalankan dalam negara mahupun di luar negara akan dipilih dalam proses menganalisis dapatan kajian. Akan tetapi, hanya kajian yang dilaksanakan oleh para pendidik iaitu guru dan responden kajian terdiri daripada golongan pendidik dan pelajar sahaja akan dipilih artikelnya dalam SLR ini.

\section{Proses Pemilihan Artikel}

Empat pangkalan data telah digunakan untuk mencari, mengenal pasti dan menentukan kesesuaian artikel supaya dapat menjawab persoalan kajian. Pangkalan data tersebut ialah Web of Science (WOS), Scopus, Semantic Scholar dan Lain-lain (Jurnal). Pada asalnya, pencarian artikel melalui beberapa pangkalan data didapati amat sukar kerana tidak menepati tajuk kajian terutamanya bagi bidang pendidikan. Rajah 1 menunjukkan gambar rajah aliran PRISMA (Tawfik et al., 2019) yang menerangkan proses pencarian dan penyaringan artikel-artikel untuk dijadikan sebagai data analisis. Terdapat 175 buah artikel yang dikenal pasti daripada keempat-empat pangkalan data tersebut. Artikel-artikel tersebut kemudiannya disaring berdasarkan kriteria yang ditetapkan sebelum masuk ke peringkat yang seterusnya.

\section{Rajah 1: Gambar Rajah Aliran PRISMA}

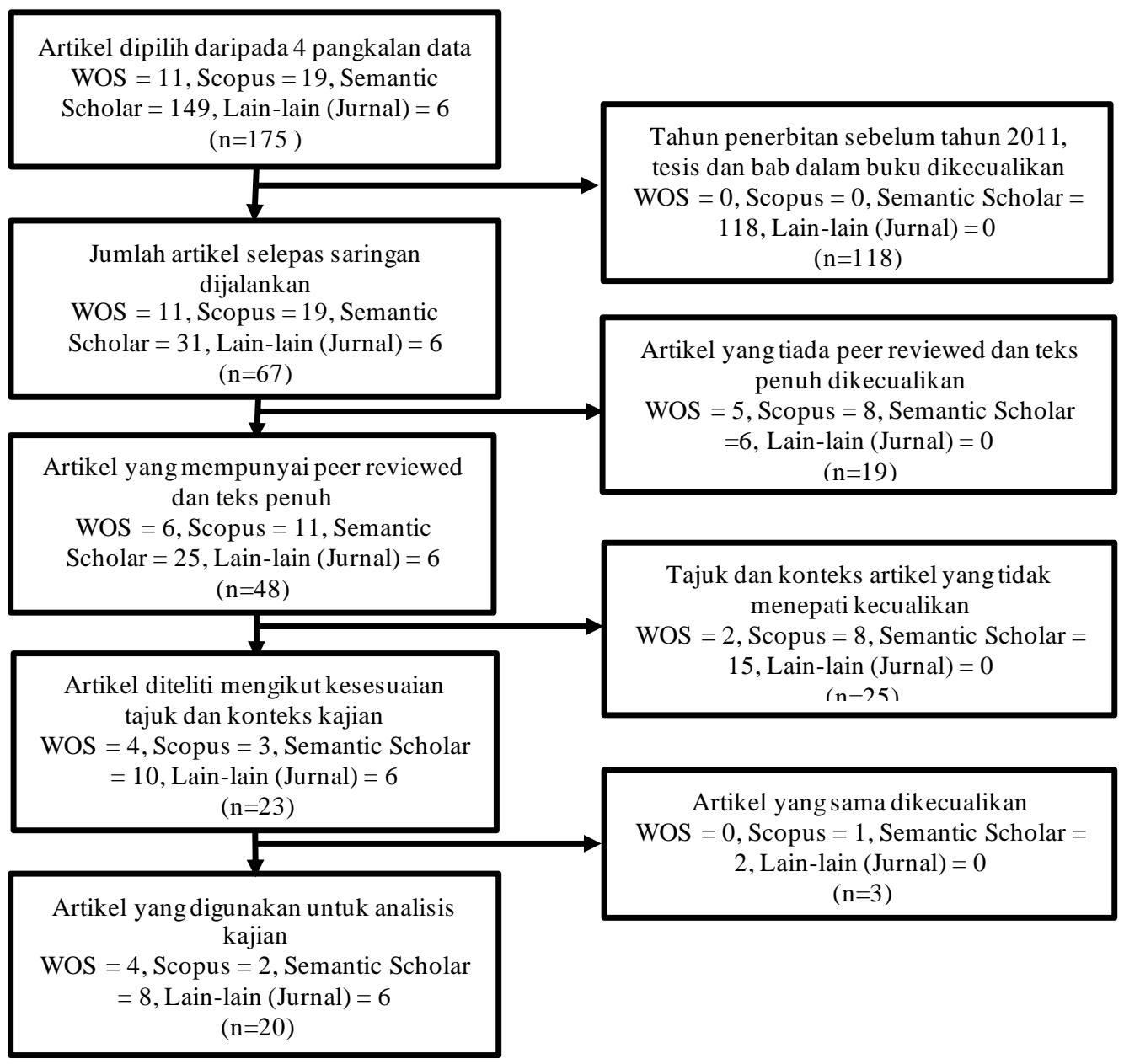

Berdasarkan Rajah 1, terdapat tiga kriteria tambahan dalam proses pengecualian artikel sebelum disahkan untuk dianalisis dalam SLR ini. Artikel yang tidak mempunyai peer-reveiwed dan bukan teks 
penuh akan dimasukkan ke dalam kategori artikel yang ditolak. Selain itu, tajuk dan konteks yang kurang sesuai dan tidak menepati dengan persoalan kajian juga dikecualikan. Kriteria tambahan terakhir pula merujuk kepada artikel yang sama dalam keempat-empat pangkalan data tersebut. Artikel yang sama telah dikecualikan.

\section{Proses Pengumpulan dan Penganalisisan Artikel}

Bagi data-data yang telah dikumpulkan, satu jadual dibina dengan menggunakan Microsoft Excel 2016. Penggunaan Microsoft Excel 2016 bertujuan untuk mengekstrak tajuk kajian, nama penulis, tahun penerbitan, latar belakang kajian, tujuan kajian, persoalan kajian dan penggunaan Model Bar pada semua peringkat pusat pendidikan. Analisis data dijalankan dengan menggunakan jadual untuk mengkategorikan strategi penggunaan Model Bar mengikut skop kajian yang ditetapkan iaitu keberkesanan Model Bar dalam PdPc matematik yang berunsurkan penyelesaian masalah.

Seterusnya, hasil analisis akan dipersembahkan dengan perwakilan data seperti graf palang, carta pai dan jadual. Artikel-artikel yang dianalisis telah menjalani proses penerimaan dan penolakan artikel berdasarkan kriteria-kriteria yang ditetapkan. Jadual 2 menunjukkan nama penulis, tahun penerbitan dan tajuk kajian bagi artikel yang dipilih.

Jadual 2: Senarai Artikel yang Dianalisis Dalam Sorotan Literatur Bersistematik

\begin{tabular}{|c|c|c|}
\hline Nama Penulis & $\begin{array}{c}\text { Tahun } \\
\text { Penerbitan }\end{array}$ & Tajuk Kajian \\
\hline $\begin{array}{l}\text { Emily Sharp \& Minyi Shih } \\
\text { Dennis }\end{array}$ & 2016 & $\begin{array}{l}\text { Model Drawing Strategy for fraction Word } \\
\text { Problem of Fourth-Grade With Learning } \\
\text { Disabilities }\end{array}$ \\
\hline $\begin{array}{l}\text { Lisa L. Morin, Silvana } \\
\text { M.R.Watson, Peggy Hester \& } \\
\text { Sharon Raver }\end{array}$ & 2017 & $\begin{array}{l}\text { The Use of a Bar Model Drawing to Teach Word } \\
\text { Problem Solving to Students With Mathematics } \\
\text { Difficulties. Learning Disability Quarterly }\end{array}$ \\
\hline $\begin{array}{l}\text { Willyarto, M.N., Pane, M. \& } \\
\text { Hairiyani, R. }\end{array}$ & 2015 & $\begin{array}{l}\text { Mathematics Learning Method of Bar Modeling } \\
\text { for Elementary School Students }\end{array}$ \\
\hline Rethlefsen. A.L., \& Park, H. & 2011 & $\begin{array}{l}\text { A Mixed-Method Study: Assessing the BAR } \\
\text { Model's Impact on Preservice Teachers' Efficacy } \\
\text { Beliefs }\end{array}$ \\
\hline $\begin{array}{l}\text { Ramesh Yanamashetti \& Dr. Anil } \\
\text { V. Bamagond }\end{array}$ & 2020 & $\begin{array}{l}\text { Effect of bar model of teaching mathematics on } \\
\text { the achievement of IX standard students }\end{array}$ \\
\hline Bulac, R.C. & 2019 & $\begin{array}{l}\text { Singapore Bar Model Approach in Teaching } \\
\text { Math VI }\end{array}$ \\
\hline Dennis, M.S., Knight, J. \& & & Teaching High School Students With Learning \\
\hline Jerman, O. & 2015 & $\begin{array}{l}\text { Disabilities to Use Model Drawing Strategy to } \\
\text { Solve Fraction and Percentage Word Problems }\end{array}$ \\
\hline $\begin{array}{l}\text { Maimunah Abdul Gani, Khairul } \\
\text { Amilin Tengah \& Hardimah Said }\end{array}$ & 2019 & $\begin{array}{l}\text { Bar Model as Intervention in Solving Word } \\
\text { Problem Involving Percentage }\end{array}$ \\
\hline $\begin{array}{l}\text { Ernie Sofinah Matzin \& } \\
\text { Lawrence Mundia }\end{array}$ & 2017 & $\begin{array}{l}\text { Effective Learning of Mathematics by Year } 7 \\
\text { Students using the Bar Model method: Case of } \\
\text { Brunei Students }\end{array}$ \\
\hline $\begin{array}{l}\text { Herani Tri Lestiana \& Cici Tri } \\
\text { Wanita } \\
\text { Sharifah Osman, Che Nurul } \\
\text { Azieana Che Yong. Mohd Salleh } \\
\text { Abu, Norulhuda Ismail, Hanifah }\end{array}$ & 2019 & $\begin{array}{l}\text { Bar Model: A Beneficial Tool in Learning } \\
\text { Percentage } \\
\text { Enhancing Students' Mathematical Problem- } \\
\text { Solving Skills through Bar Model Visualisation } \\
\text { Technique }\end{array}$ \\
\hline
\end{tabular}

Jambari \& Jeya Amantha Kumar 
Malaysian Journal of Social Sciences and Humanities (MJSSH), Volume 5, Issue 12, (page 144 - 159), 2020

DOI: https://doi.org/10.47405/mjssh.v5i12.569

Yap Ji Lin \& Siti Rahaimad Ali

Claire Hofer

Farizan Ismail

Lavina Nair, Madawan Nair \& Marzita Puteh

Lei Bao

N.A. Madani, K. A. Tengah \& R.

C. I. Prahmana

Ragu Ramasamy \& Marzita

Puteh

Ragu Ramasamy \& Marzita

Puteh

Augustine Anak Singga \&

Effandi Zakaria
The Effectiveness of Bar Model In Solving

2018 Standard Four Descriptive Mathematical Problem

2015 The Introduction of the Singapore Bar Model in Year 1 Problem Solving: A Personal Reflection

2013 Keberkesanan Kaedah Model Bar Dalam Menyelesaikan Masalah Matematik Ayat The Development of Bar Model Fraction Kit In

2019 Solving Higher Order Thinking Skills Mathematics Word Problems

2016 The Effectiveness of Using The Model Method To Solve Word Problems

Using Bar Model To Solve Word Problems On Profits, Loss And Discount Bar Model Method For Higher Order Thinking

2018 Skills Questions in Mathematics For Dual Language Program Pupils

2019 The Effectiveness of Bar Model To Enhance Hots in Mathematics For Year 4 Pupils Penggunaan Model Bar Dalam Kemahiran Penyelesaian Masalah Pecahan Tahun 6

\section{Dapatan dan Perbincangan Kajian}

\section{Pangkalan Data dan Tahun Penerbitan Artikel}

Terdapat empat pangkalan data yang telah digunakan berdasarkan kriteria proses pencarian artikel seperti yang ditunjukkan dalam Rajah 2. Berdasarkan Rajah 2, WOS, Scopus, Semantic Scholar dan Lain-lain (Jurnal) merupakan pangkalan data yang digunakan dalam pencarian artikel.

Rajah 2: Pangkalan Data Artikel Dipilih

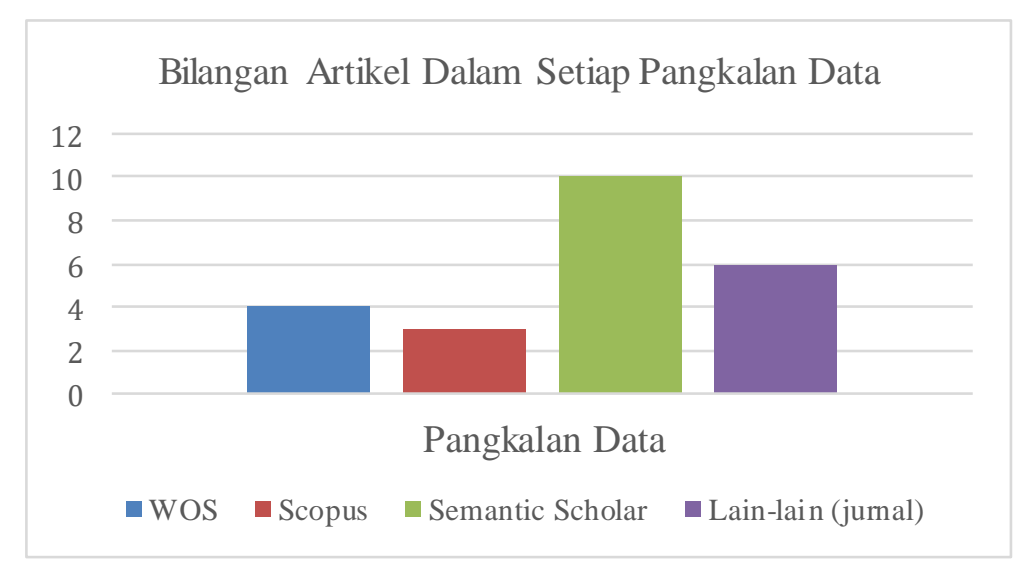

Berdasarkan Rajah 2, WOS menyumbangkan sebanyak 4 buah artikel (17.3\%), Scopus mencatatkan 3 buah artikel (13.1\%), 43.5\% artikel adalah daripada Semantic Scholar dan selebihnya iaitu $26.1 \%$ adalah daripada lain-lain pangkalan data jurnal-jurnal.

Berdasarkan Jadual 3 pula, artikel-artikel telah dikumpulkan dan disaring sejak Tahun 2011 sehingga Tahun 2020. Terdapat 7 artikel (30.4\%) diterbitkan pada Tahun 2011 sehingga Tahun 2015 dan 16 
DOI: https://doi.org/10.47405/mjssh.v5i12.569

artikel (69.6\%) diterbitkan pada Tahun 2016 sehingga Tahun 2020. Dapat dilihat bahawa kurang kajiankajian lepas mengenai pelaksanaan strategi Model Bar yang telah dijalankan.

Jadual 3: Rumusan Terhadap Pangkalan Data dan Tahun Penerbitan Artikel

\begin{tabular}{cccccc}
\hline \multirow{2}{*}{$\begin{array}{c}\text { Tahun } \\
\text { Penerbitan }\end{array}$} & WOS & Scopus & Semantic Scholar & $\begin{array}{c}\text { Lain-lain } \\
\text { (Jurnal) }\end{array}$ & Jumlah \\
\cline { 2 - 5 } & 2 & 1 & 4 & 0 & 7 \\
\hline $2011-2015$ & 2 & 2 & 6 & 6 & 16 \\
$2016-2020$ & 4 & 3 & 10 & 6 & 23 \\
Jumlah & 4 & &
\end{tabular}

\section{Lokasi Kajian}

Salah satu kriteria pemilihan artikel adalah berdasarkan kepada lokasi kajian lepas dijalankan. Rajah 3 menunjukkan lokasi kajian bagi kajian lepas yang dipilih artikelnya dalam SLR ini. Berdasarkan Rajah 3, USA dan US masing-masing menyumbang 3 buah artikel (13.1\%). Australia dan Filipina pula masingmasing menyumbangkan $4.3 \%$ artikel, India dan Brunei mewakili $8.7 \%$ daripada keseluruhan artikel. Negara Indonesia merupakan negara kedua banyak artikel yang terpilih iaitu sebanyak $17.4 \%$. Malaysia merupakan negara yang paling banyak artikelnya dipilih iaitu sebanyak 30.4\% (7 buah artikel). Namun, terdapat artikel yang sama dalam WOS, Scopus dan Semantic Scholar. Ketiga-tiga artikel yang sama telah dikecualikan dalam proses pemilihan artikel sebelum dijadikan sebagai data analisis.

Dengan itu, pengkaji mengambil keputusan untuk memilih artikel yang bersesuaian daripada artikel terbitan dalam negara dan juga luar negara. Ini kerana Model Bar berasal dari negara Singapura. Kajiankajian di Malaysia tidak begitu hangat jika berbanding dengan negara lain. Namun, terdapat peningkatan bilangan artikel kajian yang dijalankan di Malaysia sejak tahun-tahun kebelakangan ini. Hasil kajian dapat memberikan kefahaman dan pengukuhan kemahiran kepada guru-guru agar mengaplikasikan strategi Model Bar dalam PdPc matematik.

Rajah 3: Lokasi Kajian

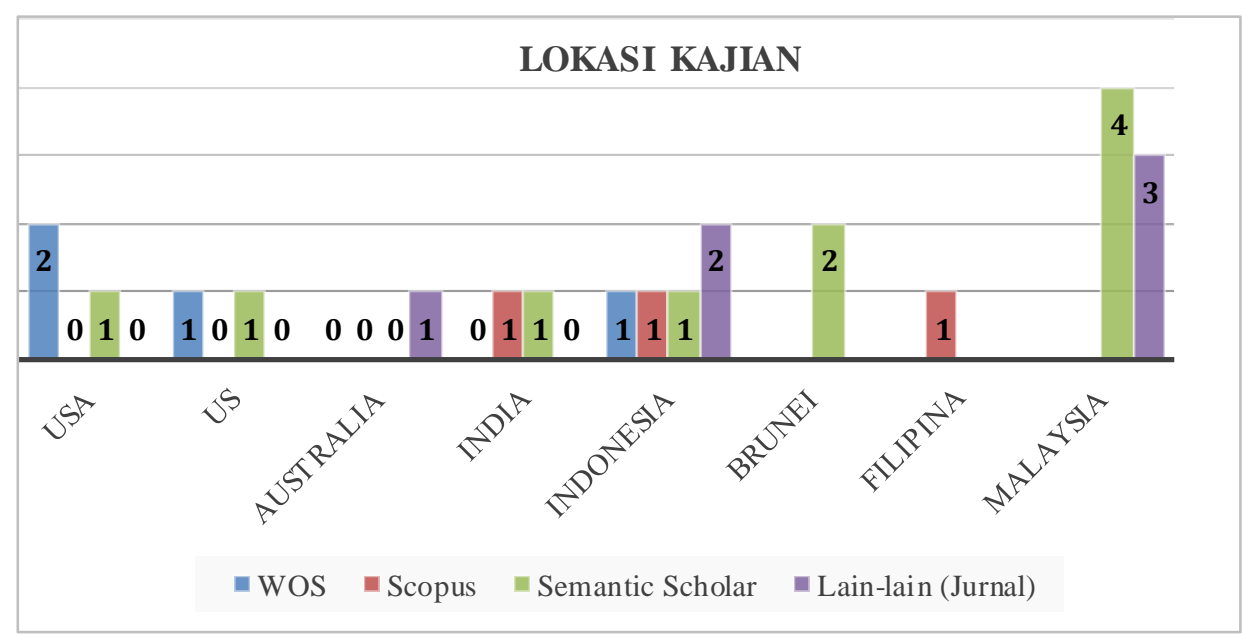

\section{Skop Kajian}

Jadual 4 menunjukkan ringkasan tujuan kajian dan skop kajian yang telah dikategorikan mengikut tiga skop kajian yang dianalisis. Berdasarkan Jadual 4 terdapat tiga skop kajian yang telah dikenal pasti selepas proses menganalisis data dilaksanakan. Skop kajian yang pertama merupakan keberkesanan penggunaan 
Model Bar terhadap penyelesaian masalah matematik dan skop kajian kedua pula merujuk kepada persepsi guru dan murid terhadap penggunaan Model Bar dalam penyelesaian masalah matematik. Manakala skop kajian ketiga menerangkan tentang perbezaan antara penggunaan strategi Model Bar dengan pendekatan konvensional terhadap pencapaian murid.

Jadual 4: Tujuan Kajian dan Skop Kajian

\begin{tabular}{cc}
\hline $\begin{array}{c}\text { Nama Penulis/ Tahun } \\
\text { Penerbitan }\end{array}$ & Tujuan Kajian \\
\hline
\end{tabular}
Skop Kajian 1:

Keberkesanan Penggunaan Model Bar Terhadap Penyelesaian Masalah Matematik

Emily Sharp \& Minyi Shih Untuk memeriksa kesan strategi lukisan model sebagai langkah Dennis. (2016) intervensi terhadap penyelesaian masalah Pecahan - meningkatkan prestasi tiga orang pelajar gred 4.

Untuk mengkaji kesan strategi penyelesaian masalah, lukisan model

Morin, L. L. et al,. (2017) Bar terhadap penyelesaian masalah matematik bagi pelajar yang mempunyai masalah pembelajaran Matematik.

Untuk mengkaji kaedah pengajaran Matematik (terutama untuk pelajar-

Willyarto, M.N., Pane, M. pelajar sekolah rendah) supaya mudah difahami oleh pelajar dengan \& hairiyani, R. (2015) menggunakan satu kaedah pembelajaran matematik yang baik iaitu penggunaan model (Model Bar).

Yanamashetti, R. \& Penyelidik menjalankan kajian eksperimen ke atas Model Bar

Bamagond, A.V. (2020)

Dennis, M. S., Knight, J., \& Jerman, O. (2015) matematik.

Maimunah Abdul Gani,

Khairul Amilin Tengah \&

Hardimah Said. (2019)

Herani Tri Lestiana \& Cici

Tri Wanita. (2019)

Sharifah Osman et al,. (2018)

Yap Ji Lin \& Siti Rahaimad Ali. (2018)

Untuk mengkaji cara mengajar penyelesaian masalah tajuk pecahan dan peratusan dengan menggunakan strategi melukis model.

Untuk mengkaji prestasi murid dalam menyelesaikan masalah

perkataan yang melibatkan peratusan dengan menggunakan Model Bar sebagai strategi penyelesaian.

Untuk menyokong pelajar dalam memahami peratusan dengan menggunakan Model Bar.

Untuk menyiasat pencapaian pelajar dalam penyelesaian masalah matematik setelah menggunakan Model Bar dan untuk meneroka pengalaman pelajar semasa mengaplikasikan teknik ini.

Untuk mengkaji pelaksanaan pendekatan model bar pada pelajar Tahun Empat dalam menyelesaikan masalah penolakan.

Mengkaji keberkesanan kaedah Model Bar dalam membantu pelajar

Farizan Ismail. (2013)

Lavina Nair Madawan

Nair, Marzita Puteh. (2019)

Bao, Lei. (2016) meningkatkan kemahiran menyelesaikan masalah mereka mengenai masalah perkataan matematik.

Tujuan kajian ini adalah untuk mengembangkan dan mengesahkan Model Bar Kit Pecahan.

Untuk menyiasat sama ada kaedah-kaedah berkesan untuk membantu pelajar sekolah rendah untuk menyelesaikan masalah berayat.

Madani, N. A., Tengah, K. A., \& Prahmana, R. C. I. (2018)

Ramasamy, R., \& Puteh, M. (2018)

Singga, Augustine Anak \& Zakaria, Effandi. (2020)

Untuk mengkaji penggunaan Model Bar untuk membantu pelajar di sebuah sekolah kerajaan di Brunei dalam menyelesaikan masalah yang melibatkan keuntungan, kerugian dan diskaun.

Untuk memeriksa keberkesanan wakil Model Bar untuk menyelesaikan

Kemahiran Berfikir Aras Tinggi (KBAT) soalan untuk murid kelas Dual Language Programme (DLP) tahun 6 di SK Bukit Bandaraya.

Untuk mengkaji penggunaan model bar dalam menyelesaikan matematik masalah berayat pecahan.

Skop Kajian 2 :

Persepsi guru dan murid terhadap penggunaan Model Bar dalam penyelesaian masalah Matematik 
Rethlefsen, A. L., \& Park, H. (2011)

Ernie Sofinah Matzin \& Lawrence Mundia. (2017)

Claire Hofer. (2015)
Menentukan sama ada kaedah pengajaran tertentu dari model Bar yang membawa kepada perubahan positif dalam kepercayaan keberkesanan guru pra-perkhidmatan.

Untuk meneliti sikap dan persepsi pelajar terhadap Kaedah Pembelajaran Bar Model.

Untuk menilai pengaruh saya terhadap pembelajaran anak-anak dengan memperkenalkan model bar Singapura kepada sekumpulan kanakkanak Tahun 1 dan kesannya terhadap penyelesaian masalah mereka. Skop Kajian 3 :

Perbezaan antara penggunaan strategi Model Bar dengan pendekatan konvensional terhadap pencapaian murid

Bulac, R. C. (2019)

Rosiana Mufliva \& Tatang Herman. (2018)
Untuk mengkaji persepsi murid dan menilai keberkesanan menggunakan pendekatan model Bar Singapura dalam meningkatkan prestasi matematik daripada pelajar gred VI sekolah rendah.

Untuk mendapatkan gambaran keseluruhan perbezaan dalam peningkatan keupayaan untuk mewujudkan model matematik dan kemahiran prosedural memperoleh model Bar dan pembelajaran berpusatkan guru.

Rajah 4 pula menunjukkan analisis terhadap tiga skop kajian yang dikenal pasti dan dikategorikan dalam Jadual 4 di atas. Berdasarkan Rajah 4, terdapat sebanyak 15 buah artikel (75\%) berkaitan dengan skop kajian yang pertama iaitu keberkesanan penggunaan Model Bar terhadap penyelesaian masalah matematik. Malah 3 buah artikel (15\%) dikenal pasti tergolong dalam skop kajian kedua iaitu persepsi guru dan murid terhadap penggunaan Model Bar dalam penyelesaian masalah matematik. Manakala skop kajian ketiga iaitu perbezaan antara penggunaan strategi Model Bar dengan pendekatan konvensional terhadap pencapaian murid mengumpul sebanyak 2 buah artikel bersamaan dengan $10 \%$.

Rajah 4: Skop Kajian Artikel

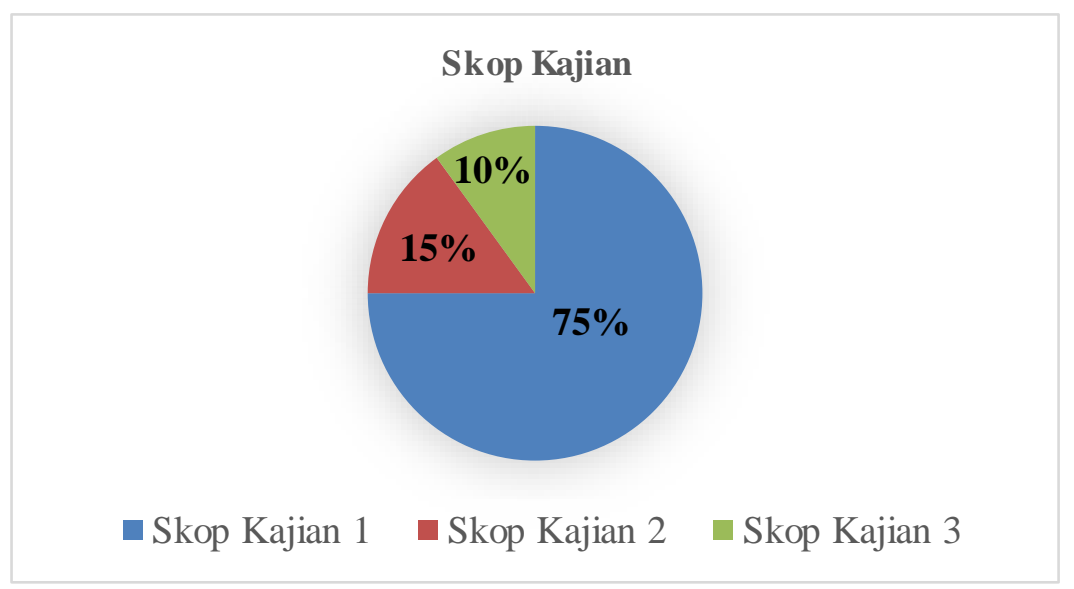

\section{Keberkesanan Penggunaan Strategi Model Bar Terhadap Penyelesaian Masalah Matematik}

Keberkesanan penggunaan strategi Model Bar terhadap penyelesaian masalah matematik merupakan objektif utama dalam sorotan kajian literatur ini. Murid mempunyai masalah yang besar dalam memahami masalah dengan mengeluarkan isi tersirat dan isi tersurat dalam pernyataan masalah (Newman, 1997).

Kajian Singga dan Zakaria (2020) menjelaskan bahawa penggunaan Model Bar dapat membantu murid menguasai kemahiran penyelesaian masalah berayat pecahan dengan baik. Hal ini bertepatan dengan kajian Lavina dan Marzita (2019) bahawa Model Bar bagi kit pecahan secara langsung memberi peluang kepada murid untuk menguasai konsep pecahan. Selain itu, strategi Model Bar sesuai dan berkesan juga 
untuk diaplikasikan dalam PdPc matematik terhadap penyelesaian masalah bagi tajuk-tajuk seperti peraturan, penambahan dan penolakan nombor, wang dan sebagainya.

Model bar boleh membantu pelajar membina pengetahuan antara nombor dengan peratusan dan juga membantu mereka menyelesaikan masalah peratusan secara sistematik melalui langkah-langkah tertentu (Herani \& Cici, 2019). Sifat visualisasi Model Bar membolehkan pelajar untuk mengorganisasikan maklumat yang diberi dan memikirkan langkah penyelesaian yang sesuai bagi masalah yang kompleks dan mencabar minda. Kenyataan ini bertepatan dengan hasil kajian Maimunah et al. (2019) membuktikan bahawa terdapat peningkatan menyeluruh dalam prestasi pelajar bagi masalah berayat yang berkaitan dengan tajuk peratusan apabila Model Bar diaplikasikan sebagai proses intervensi PdPc matematik.

Selain itu, Model bar juga sesuai digunakan bagi murid yang menghadapi kesukaran dalam pembelajaran matematik (Learning Mathematics Difficulties). Hasil dapatan kajian menunjukkan bahawa lukisan Model Bar adalah strategi yang berkesan untuk meningkatkan konsep asas dalam menyelesaikan masalah perkataan matematik dan keupayaan mereka untuk menggunakan strategi kognitif untuk menyelesaikan masalah (Morin et al,. 2017). Model Bar juga membantu murid yang menghadapi masalah ketidakupayaan pembelajaran dalam konsep matematik. Namun, kesukaran ini dapat diatasi dengan mengaplikasikan semua peringkat penyelesaian masalah Mayer (1985) dan disokong oleh Model Bar. Hasil dapatan kajian Emily dan Minyi (2016) menunjukkan langkah intervensi selama 2 hingga 4 minggu dengan menggunakan Model Bar adalah berkesan untuk memperbaiki masalah ketidakupayaan pelajar bagi menyelesaikan masalah matematik.

Yanamashetti \& Bamagond (2020) menyatakan Model Bar diaplikasikan jika pengajaran matematik adalah lebih berkesan dan diterima oleh murid. Sekiranya teknik pengajaran tradisional tidak membuahkan hasil yang berkesan, maka intervensi seharusnya dilaksanakan dari semasa ke semasa. Pelajar belajar dengan lebih berkesan kerana Model Bar dapat menarik perhatian dan minat mereka serta mengekalkan konsep Model Bar dalam ingatan serta kefahaman mereka. Prosedur langkah demi langkah untuk menggunakan strategi Model Bar dapat membantu menyelesaikan masalah ketidakupayaan pembelajaran bagi sesetengah murid (Emily \& Minyi, 2016).

Kebanyakan murid masih tidak biasa mengaplikasikan Model Bar kerana jarang digunakan oleh mereka dalam PdPc matematik. Akan tetapi hasil dapatan kajian Madani et al. (2018) melaporkan dengan adanya praktik yang banyak dan kerap, Model Bar merupakan satu strategi penyelesaian masalah yang berkesan dan dapat meningkatkan kecekapan pelajar untuk menyelesaikan masalah matematik. Melukis bar bertujuan untuk membimbing murid belajar menyelesaikan masalah dengan pelbagai strategi dan bukan hanya mengikut satu strategi sahaja. Strategi Model Bar dijadikan alat kepada murid untuk mengukuhkan pemahaman dan mengenal pasti hubungan antara operasi dan penyelesaian yang sesuai supaya dapat menemui jawapan yang munasabah. Ini turut disokong oleh hasil kajian Bao (2016) bahawa pelajar diberi peluang untuk mentafsirkan masalah dengan melukis bar segi empat tepat bagi melambangkan situasi masalah dengan penyelesaiannya yang betul dan tepat.

Penerapan KBAT dalam kurikulum matematik sekolah rendah telah bermula sejak Tahun 2011. Fokus utama soalan matematik UPSR akan bertambahnya bentuk subjektif yang berunsurkan elemen KBAT. Keputusan UPSR bagi mata pelajaran matematik mencatatkan $80.5 \%$ mencapai gred A hingga D (lulus) berbanding dengan tahun 2019 yang memberikan kelulusan sebanyak 83.13\%. Ini memberikan satu keyakinan kepada para pendidik bahawa walaupun elemen KBAT semakin tinggi peratusannya diterapkan dalam soalan UPSR, namun murid kita masih mampu menjawab dengan baik. Oleh itu, peranan guru sangat penting dalam usaha mengembangkan kemahiran berfikir pelajar supaya pemikiran pelajar menjurus kepada pemikiran yang kreatif dan kritis (Singga \& Zakaria, 2020). Model Bar hendaklah diperkenalkan pada peringkat awal persekolahan murid supaya kognitif mereka akan berkembang selaras dengan umur mereka.

\section{Persepsi Guru dan Murid Terhadap Penggunaan Strategi Model Bar Dalam Penyelesaian Masalah Matematik}


Model bar merupakan satu pendekatan di bawah Teori Piaget dengan menekankan pembinaan pengetahuan oleh murid sendiri melalui pengalaman, asimilasi dan pemahaman idea tersebut. Guru memainkan peranan yang utama dalam usaha mendedahkan strategi Model Bar kepada murid di sekolah. Konsep penyelesaian masalah yang memerlukan pemikiran aras tinggi menggalakkan murid mengaplikasikan pelbagai pendekatan penyelesaian yang sesuai dan menepati kehendak soalan. Hasil dapatan kajian Krongthong Khairiree (2012) yang telah menguji Model Bar di sekolah rendah mendapati sikap murid positif terhadap penggunaan Model Bar kerana murid dapat membuat perwakilan. Ini kerana kaedah model bar ini melahirkan rasa positif dan ia dapat memberikan motivasi kepada murid untuk menjawab soalan yang berbentuk penyelesaian masalah berayat.

Guru seharusnya memberi tumpuan utama terhadap pembangunan profesional kendiri bagi meningkatkan amalan pengajaran. Usaha ini dapat menghasilkan pembelajaran yang lebih berkesan dan mencapai objektif PdPc yang eksplisit. Pendekatan Model Bar hendaklah didedahkan seawal murid di usia yang muda di sekolah rendah. Pandangan ini turut disokong kajian Claire (2015) menyatakan "melalui Model Bar saya telah mengesan kepentingan pengalaman konkrit agar kanak-kanak mendapat kefahaman sesuatu konsep matematik dan mampu merapatkan jurang antara konkrit dan abstrak, terutamanya bagi anak murid muda".

Strategi Model Bar seharusnya dimasukkan dalam kurikulum pendidikan guru bagi guru pra-perkhidmatan dan dalam perkhidmatan. Dengan ini, guru diharapkan akan berkemahiran untuk mengaplikasikan kaedah Model Bar dengan cekap dan berkesan dalam proses PdPc matematik. Apabila murid memahami penggunaan Model Bar sebagai teknik visualisasi mereka akan dapat menyelesaikan masalah dengan yakin dan berusaha ke arah pencapaian yang lebih tinggi. Hasil dapatan kajian Ernie (2018) menunjukkan tiada perbezaan yang ketara pada skor ujian sebelum dan selepas mengikut jantina dan umur pada ujian pencapaian penyelesaian matematik dengan menggunakan strategi Model Bar. Hasil kajian ini telah meyakinkan kita bahawa strategi Model Bar dikuasai oleh murid tanpa mengira jantina dan umur apabila mereka dibimbing cara mengaplikasikannya dalam soalan berbentuk penyelesaian masalah yang berayat.

Selain itu, perubahan tingkah laku dan amalan pengajaran seseorang guru amat penting dalam menjayakan sistem pendidikan negara Malaysia. Usaha guru yang seiring dengan matlamat pendidikan Malaysia dapat menjamin keberkesanan penggunaan strategi PdPc tertentu. Hasil kajian Rethelefsen (2011) menyatakan guru berpandangan bahawa penggunaan strategi Model Ber membolehkan guru untuk mempelajari kaedah pengajaran secara hands-on berasaskan pengetahuan dan konsep matematik yang dikuasai sebelum ini. Pendekatan Model Bar juga memberi pendedahan kepada guru dan murid daripada menggunakan pendekatan berpusatkan guru atau arahan langsung kepada suatu pendekatan yang lebih membina. Guru yang berkesan lebih cenderung menggunakan pelbagai strategi pengajaran yang berpusatkan murid dan inkuiri penemuan. Ini turut disokong oleh kajian Singga dan Zakaria (2020) bahawa ia juga melahirkan perasaan gembira, seronok, yakin dan aktif dalam kalangan responden semasa menjalankan pengajaran dan pembelajaran kemahiran masalah berayat pecahan.

\section{Perbezaan Antara Penggunaan Strategi Model Bar Dengan Pendekatan Konvensional Terhadap Pencapaian Murid}

Terdapat banyak penyelidikan telah dijalankan terhadap KBAT dan penyelesaian masalah terutamanya pendidikan matematik. Ini kerana elemen KBAT merupakan satu elemen yang telah dan wajib didedahkan dalam PdPc matematik bagi menyediakan murid menangani cabaran pada masa yang akan datang. Hasil dapatan kajian Rosiana dan Tatang (2018) menunjukkan Model Bar dapat meningkatkan kemampuan pelajar membina model matematik jika berbanding dengan pembelajaran tradisional yang melalui pendekatan berpusatkan guru. Ini kerana penggunaan Model Bar boleh bertahan lama dalam ingatan murid terutamanya apabila mereka ingin menyelesaikan masalah matematik yang lebih tinggi aras kognitifnya.

Bulac (2000) juga menjelaskan bahawa pendekatan tradisional dan Model Bar yang diperkenalkan oleh negara Singapura adalah sama keberkesanannya dalam PdPc matematik. Namun, hasil kajian menunjukkan terdapat peningkatan yang signifikan dalam skor ujian murid. Ini disebabkan pendekatan Model Bar lebih mudah difahami oleh murid ketika terutamanya ketika mereka menjawab soalan masalah 
bukan rutin yang memerlukan kemahiran menyelesaikan masalah yang berbagai. Model Bar boleh dijadikan satu strategi yang sangat berkesan penggunaannya bagi meningkatkan prestasi akademik para pelajar.

\section{Kesimpulan}

Penyelesaian masalah merupakan satu konsep yang sukar dan sering dijadikan masalah kepada murid sekolah rendah mahupun sekolah menengah. Dengan lukisan model, pelajar akan belajar untuk menyelesaikan masalah berayat yang sangat mencabar pemikiran mereka. Model Bar membantu murid mencapai pemahaman mengenai bagaimana masalah boleh diselesaikan dengan strategi yang mudah dan berkesan. Murid didedahkan dengan pelbagai strategi penyelesaian masalah supaya mereka berkeupayaan menyelesaikan masalah bukan sahaja dalam matematik tetapi juga masalah dalam kehidupan seharian.

Hasil daripada dapatan kajian, pengkaji ingin menyarankan beberapa cadangan yang boleh dijadikan sebagai panduan atau tindakan susulan bagi memperkukuhkan lagi pelaksanaan strategi Model Bar dalam PdPc matematik. Pengkaji mencadangkan kepada guru supaya mendedahkan dan mengaplikasikan strategi Model Bar seawal murid di Tahun 1 mahupun pra-sekolah. Penggunaan pendekatan atau strategi PdPc yang berkesan adalah penting dalam membantu meningkatkan tahap pemikiran murid yang lebih kreatif dan kritis. Pengkaji juga mencadangkan agar Kementerian Pendidikan Malaysia merancang dan mengelola pelbagai Latihan Dalam Perkhidmatan (LADAP) mengenai strategi Model Bar bagi menyampaikan pengetahuan dan pelaksanaannya kepada para pendidik terutamanya guru pra-perkhidmatan. Di samping itu, pendekatan Model Bar sesuai diaplikasikan dalam banyak kemahiran matematik seperti pecahan, peratusan, jisim, nombor bulat dan sebagainya. Oleh itu, guru sewajarnya menguasai penggunaan Model Bar dan diterapkan dalam proses PdPc matematik bagi menyelesaikan masalah bukan rutin yang mengandungi elemen Kemahiran Berfikir Aras Tinggi.

\section{Rujukan}

Bulac, R. C. (2019). Singapore Bar Model Approach in Teaching Math VI. Journal of Physics: Conference Series, 1254(1). doi:10.1088/1742-6596/1254/1/012078

Bao, Lei.. (2016). The effectiveness of using the model method to solve word problems. Australian Primary Mathematics Classroom, 21(3), 26-31. Diperoleh https://search.informit.com.au/document Summary; $\mathrm{dn}=350410101707306$;res=IELHSS

Chan, C. M. E. \& Foong, P. Y. (2013). A conceptual framework for investigating pupils' model development during the mathematical modelling process. The Mathematics Educator, 15(1), 1-29.

Claire Hofer. (2015). The Introduction of the Singapore Bar Model in Year 1 Problem Solving: A Personal Reflection. The Step Journal, 2(2), 107-117.

Dennis, M. S., Knight, J., \& Jerman, O. (2015). Teaching High School Students With Learning Disabilities to Use Model Drawing Strategy to Solve Fraction and Percentage Word Problems. Preventing School Failure: Alternative Education for Children and Youth, 60(1), 10-21. doi:10.1080/1045988 x.2014.954514

Dewey, A. \& Drahota, A. (2016). Introduction to systematic reviews: online learning module Cochrane Training. Diperoleh https://training.cochrane.org/interactivelearning/m odule-1-introduction-cond ucting-systematic-reviews

Emily Sharp \& Minyi Shih Dennis. (2016). Model Drawing Strategy for Fraction Word Problem Solving of Fourth-Grade Students With Learning Disabilities. Remedial and Special Education, 38(3), 181192. doi: $10.1177 / 0741932516678823$

Englard, L. (2010). Raise the bar on problem solving. Teaching Children Mathematics, 17(3), 156-164.

Ernie Sofinah Matzin \& Lawrence Mundia. (2011). Effective Learning of Mathematics by Year 7 Students using the Bar Model Method: Case of Brunei Students. Journal of Studies in Education, 8(1), 1-16. doi:10.5296/jse.v8i1.12177

Ismail, Farizan. (2013). Keberkesanan kaedah Model Bar dalam menyelesaikan masalah matematik berayat. (Masters thesis, Universiti Teknologi Malaysia, Faculty of Education). 
Herani Tri Lestiana \& Cici Tri Wanita. (2019). Bar Model: A Beneficial Tool in Learning Percentage. EduMa: Mathematics Education Learning And Teaching, 8(2), 18-27. doi:10. 24235/eduma.v8i2.5 392

IEA Trends in International Mathematics and Science Study. (2003). International mathematics report. Diperoleh dari http://timss.bc.edu/timss2003i/mathD. html

International Association for the Evaluation of Educational Achievement (IEA). (2013). Released mathematics items. Diperoleh dari https://nces.ed.gov/timss/pdf/TIMSS2011G4_Math.pdf

International Association for the Evaluation of Educational Achievement (IEA). (2013). Released mathematics items. Diperoleh dari https://nces.ed.gov/timss/pdf/TIMSS2011G8_Math.pdf

Ji Lin, Y., \& Ali, S. R. (2018). Keberkesanan pendekatan model bar dalam penyelesaian masalah berayat Matematik Operasi Tolak Tahun Empat. Jurnal Pendidikan Sains Dan Matematik Malaysia, 8(2), 35-44. https://doi.org/10.37134/jpsmm.vol8.2.4.2018

Lavina Nair Madawan Nair, Marzita Puteh. (2019). The Develoment Of Bar Model Fraction Kit In Solving Higher Order Thinking Skills Mathematics Word Problems. Sci.Int.(Lahore), 31(6),797801. Diperoleh http://www.sci-int.com/pdf/637089697698537 496.edited.pdf

Lembaga Peperiksaan. (2013). Pentaksiran kemahiran berfikir aras tinggi. Putrajaya: Kementerian Pendidikan Malaysia.

Madani, N. A., Tengah, K. A., \& Prahmana, R. C. I. (2018). Using bar model to solve word problems on profit, loss and discount. Journal of Physics: Conference Series, 1097. doi:10. 1088/1742-6596/109 $7 / 1 / 012103$

Mahoney, K. (2012). Effects of singapore's model method on elementary student problem-solving performance: single case research (Education Doctoral Theses. College of professional Studies Northeastern University Boston, Massachusetts). Diperoleh http://hdl.handle.net/2 047/d20002962

Maimunah Abdul Gani, Khairul Amilin Tengah \& Hardimah Said. (2019). Bar Model as Intervention in Solving Word Problem Involving Percentage. International Journal on Emerging Mathematics Education, 3(1), 69-76. doi:10.12928/ijeme.v3i1.11093

Malaysia Education Blueprint. (2013). Malaysia Education Blueprint 2013 - 2025. Education, 27(1), 1268. https://doi.org/10.1016/j.tate.2010.08.007

Marzita Puteh, Nor'ain Mohd Tajudin, Mazlini Adnan \& Azrul Azwan Mohd Abdul Aziz. (2017). The Utilization of Bar Model Method in Year 5 Mathematics Learning Based on HOTS. International Journal of Advanced Biotechnology and Research (IJBR), 8(3),56-63. Diperoleh https://www.resear chgate.net/publication/322203128

Salleh, Mohd Salahuddin (2006) Penyelesaian Masalah Matematik (ungkapan Dan Persamaan Kuadratik). (Bachelor's thesis, Universiti Teknologi Malaysia). Diperoleh http://www.fp.u tm.my/epusatsumber/pdffail/ptkghdfwp2/p_2006_6752_dfa26538e58b4c ccad36799c19fb9a6a.pdf

Morin, L. L. et al,. (2017). The Use of a Bar Model Drawing to Teach Word Problem Solving to Students With Mathematics Difficulties. Learning Disability Quarterly. Learning Disability Quarterly, 40(2), 91-104. doi:10.1177/0731948717690116journals. sagepub.co m/home/ldq

Newman, M. A. (1977). An analysis of sixth-grade pupils' errors on written mathematica tasks. Victorian Institute for Educational Research Bulletin, 39, 31-43.

Pittway, L. (2008). Systematic literature reviews. In Thorpe, R. \& Holt, R. The SAGE dictionary of qualitative management research. doi:10.4135/9780857020109

Ramasamy, R., \& Puteh, M. (2018). Bar Model Method for Higher Order Thinking Skills Questions in Mathematics for Dual Language Program Pupils. International Journal of Academic Research in Business and Social Sciences, 8(9), 1456-1462. doi:10.6007/IJARB SS/v8-i9/4855

Ramasamy, R., \& Puteh, M. (2019). The Effectiveness of Bar Model to Enhance HOTs in Mathematics for Year 4 Pupils. International Journal of Academic Research in Progressive Education and Development, 8(2), 200-204. DOI: 10.6007/IJARPED/v8-i2/5695

Ramesh Yanamashetti. (2020). Effect of Singapore Model (Bar model) of teaching Mathematics on the Achievement of IX Standard students Using Linear Equations. Studies in Indian Place Names, 40, 156-163. Diperoleh https://scholar.google. com/scholar?hl=en\&assdt=0\% 2C5\&q=Effect+of + bar+ model+of+teaching+mathematics+on+the+achievement+of+IXstandard+students\&btnG=

Rethlefsen, A. L., \& Park, H. (2011). A Mixed-Method Study: Assessing the BAR Model's Impact on Preservice Teachers' Efficacy Beliefs. School Science and Mathematics, 111(3), 102-117. doi:10.11 11/j.1949-8594.2010.00067.x 
Rosiana Mufliva \& Tatang Herman. (2016). Penggunaan Bar Model Unutk Meningkatkan Kemampuan Membuat Model Matematis Dan Keterampilan Prosedural Serta Ketekunan Belajar Siswa Sekolah Dasar. Diperoleh https://media.neliti.com/media/publications/1245 87-IDpenggun aan-bar-modelu ntuk-meningkatkan-k.pdf

Sharifah Osman, Che Nurul Azieana Che Yong. Mohd Salleh Abu, Norulhuda Ismail, Hanifah Jambari \& Jeya Amantha Kumar. (2018). Enhancing Students' Mathematical Problem-Solving Skills through Bar Model Visualisation Technique. International Electronic Journal Of Mathematics Education, 13(3), 273-279. doi:10.12973/iejme/3919

Singga, Augustine Anak \& Zakaria, Effandi. (2020). Penggunaan Model Bar Dalam Kemahiran Penyelesaian Masalah Pecahan Tahun 6. Jurnal Dunia Pendidikan, 2(1), 113-124. Diperoleh http://myjms.moe.gov.my/ index.php/jdpd/article/view/8332.

Tawfik, G. M., Dila et, al. (2019). A step by step guide for conducting a systematic review and metaanalysis with simulation data. Tropical Medicine dan Health, 47(1): 1-9. doi:10.1186/s41182-0190165-6

Willyarto, M.N., Pane, M. \& Chairiyani, R. (2015). Mathematics Learning Method of Bar Modeling for Elementary School Students. Advanced Science Letters, 21(7), 2328-2331. doi:10.1166/asl.2015.62 66

Yanamashetti, R. \& Bamagond, A.V. (2020). Effect Of bar model of teaching mathematics on the achievement of IX standard students. International Journal of Psychosocial Rehabilitation, 24(6): 1543-1549. 